Makalah dalam Seminar Nasional Pekan IImiah Tahunan Ikatan Geograf Indonesia Tahun 2015

Jakarta, Universitas Indonesia

\title{
KARAKTERISTIK HIDROGEOKIMIA AIRTANAH DI PESISIR KABUPATEN DEMAK, JAWA TENGAH
}

\author{
Muh Aris Marfai, Ahmad Cahyadi, Guruh Krisnantara, dan Gin Gin Gustiar \\ Jurusan Geografi Lingkungan Fakultas Geografi Universitas Gadjah Mada \\ Email: arismarfai@yahoo.com, ahmadcahyadi@geo.ugm.ac.id
}

Kawasan pesisir merupakan wilayah yang memiliki kompleksitas kegiatan manusia yang tinggi. Hal ini nampak dari banyaknya penggunaan lahan yang ada di kawasan ini. Banyaknya aktivitas manusia di kawasan pesisir tentunya memerlukan banyak air, mengingat air merupakan kebutuhan vital bagi manusia. Namun demikian, seiring dengan perkembangan kawasan pesisir proses intrusi air laut sering kali menyebabkan rusaknya kualitas airtanah, sehingga jumlah air yang dapat dimanfaatkan semakin berkurang jumlahnya. Penelitian ini bertujuan untuk (1) menganalisis tipe hidrogeokimia airtanah di Pesisir Kabupaten Demak, Jawa Tengah, dan (2) menganalisis evolusi hidrogeokimia airtanah di Pesisir Kabupaten Demak, Jawa Tengah. Analisis karakteristik hidrogeokimia dilakukan dengan analisis unsur mayor dengan membuat diagram stiff dan diagram piper. Hasil analisis menunjukkan bahwa tipe hidrogeokimia untuk empat sampel adalah $\mathrm{MgCl}_{2}$ yang menunjukkan pengaruh intrusi air laut dan tipe $\mathrm{Na}(\mathrm{K}) \mathrm{HCO}_{3}$. Tipe hidrogeokimia yang dominan berdasarkan diagram piper adalah $\mathrm{Mg}(\mathrm{Ca}) \mathrm{Cl}\left(\mathrm{SO}_{4}\right)$ sebanyak empat sampel, $\mathrm{CaMgHCO}_{3}$ satu sampel dan $\mathrm{Na}(\mathrm{K}) \mathrm{Cl}\left(\mathrm{SO}_{4}\right)$. Berdasarkan kajian tersebut, diketahui bahwa tipe hidrogeokimia dari airtanah di lokasi kajian mengalami evolusi dari tipe $\mathrm{CaHCO}_{3}$ menjadi $\mathrm{MgCl}_{2}$ sebagai air payau dan menjadi $\mathrm{Na}(\mathrm{K}) \mathrm{Cl}$ sebagai air asin.

Kata Kunci: Airtanah, Pesisir, Hidrogeokimia, Evolusi, Kabupaten Demak

\section{PENDAHULUAN}

\section{Latar Belakang}

Kawasan pesisir merupakan pertemuan ekosistem darat dan laut yang kaya akan sumberdaya (Marfai dan King, 2008a). Selain itu, kawasan pesisir merupakan kawasan yang multi-purpose, sehingga banyak kegiatan manusia yang menempati kawasan tersebut (Marfai dan King, 2008b). Rata-rata sekitar 1,2 milyar orang tinggal pada area pesisir dengan panjang $100 \mathrm{~km}$ (Wetzelhuetter, 2013). Selain itu, sekitar 50 juta orang bermigrasi ke wilayah pesisir setiap tahunnya untuk mendapatkan pekerjaan (Dragoni dan Sukhija, 2008).

Semakin meningkatnya jumlah penduduk dan aktivitas di kawasan pesisir, maka jumlah pemanfaatan airtanah akan semakin tinggi pula (Bryan, 2005; Lagudu et.al., 2013). Kondisi ini kemudian akan memicu pengambilan airtanah secara berlebih untuk dapat memenuhi kebutuhan air (Sherif et.al., 2013). Hal ini karena airtanah merupakan sumber airtawar yang paling banyak setelah air tawar dalam bentuk es dan kualitasnya relatif terjaga (Fetter, 1988; Younger, 2007). Contoh pemanfaatan airtanah yang banyak di antaranya adalah pemanfaatan airtanah oleh 
penduduk di dua belas provinsi yang terletak di pesisir China. Sekitar 60\% dari kebutuhan air bersih dari sekitar 1,3 milyar penduduk wilayah tersebut disuplai dari airtanah (Wetzelhuetter, 2013). Selain itu, airtanah juga telah mampu mensuplai 20\% kebutuhan air bersih di Amerika Serikat (Bryan, 2005). Kondisi tersebut kemudian banyak menyebabkan kasus intrusi air laut di kawasan pesisir (Gilli et.al., 2012).

Kerusakan sumberdaya airtanah yang semakin parah ini kemudian di ikuti dengan terjadinya proses perubahan iklim yang diperkirakan akan menyebabkan bahaya intrusi air alut akan semakin meningkat (Dragoni dan Sukhija, 2008). Perubahan iklim akan menyebabkan kenaikan muka air laut yang kemudian menyebabkan terjadinya pengurangan daratan dan luas akuifer yang menampung airtanah IPCC, 2007). Selain itu, perubahan iklim akan menyebabkan perubahan jumlah curah hujan, intensitas curah hujan, evapotranspirasi dan perubahan penggunaan lahan yang kemudian menyebabkan berubahnya imbuhan airtanah (Meyboom, 1967; Winter, 1999; Ducci dan Tranfaglia, 2008; Polemio dan Cassarano, 2008). Oleh karena itu, maka kajian terkait dengan intrusi air laut di kawasan pesisir menjadi sangat penting sebagai upaya memahami karakteristik sumberdaya airtanah dan sebagai bahan pertimbangan mitigasi perubahan iklim dan pengelolaan sumberdaya airtanah di masa mendatang.

Penelitian ini dilakukan di Kabupaten Demak, Provinsi Jawa Tengah. Wilayah ini merupakan bagian dari jalur utara Pulaua Jawa yang mengalami perkembangan cukup pesat yang dipengaruhi pula oleh berkembangnya Kota Semarang. Penelitian ini mengkaji karakteristik hidrogeokimia airtanah yang nantinya akan digunakan untuk mengetahui seberapa besar dampak intrusi air laut yang terjadi di lokasi kajian. Kajian ini diharapkan mampu memberikan masukan kepada pihak terkait dengan upaya-upaya penyelamatan lingkungan, konservasi sumberdaya airtanah, perencanaan sistem air bersih dan pengembangan wilayah.

\section{Tujuan Penelitian}

Tujuan penelitian dalam makalah ini terdiri dari dua tujuan, yaitu:

1. menganalisis tipe hidrogeokimia airtanah di Pesisir Kabupaten Demak, Jawa Tengah; dan

2. menganalisis evolusi hidrogeokimia airtanah di Pesisir Kabupaten Demak, Jawa Tengah. 


\section{METODE PENELITIAN}

\section{Alat dan Bahan}

Alat dan bahan yang digunakan dalam penelitian ini meliputi:

1. Botol sampel;

2. Water quality test kit;

3. Peta geologi;

4. Peta hidrogeologi;

5. Peta Rupa Bumi Indonesia (RBI);

6. Seperangkat komputer dengan software ArcGis dan Rockwork.

\section{Pengambilan Sampel Airtanah}

Jumlah sampel yang diambil dalam penelitian ini sejumlah enam sampel yang berasal dari airtanah. Sampel diambil dengan mempertimbangkan jarak terhadap pantai dengan harapan mendapatkan variasi pengaruh intrusi air laut di lokasi kajian. Lokasi pengambilan sampel ditunjukkan oleh Gambar.

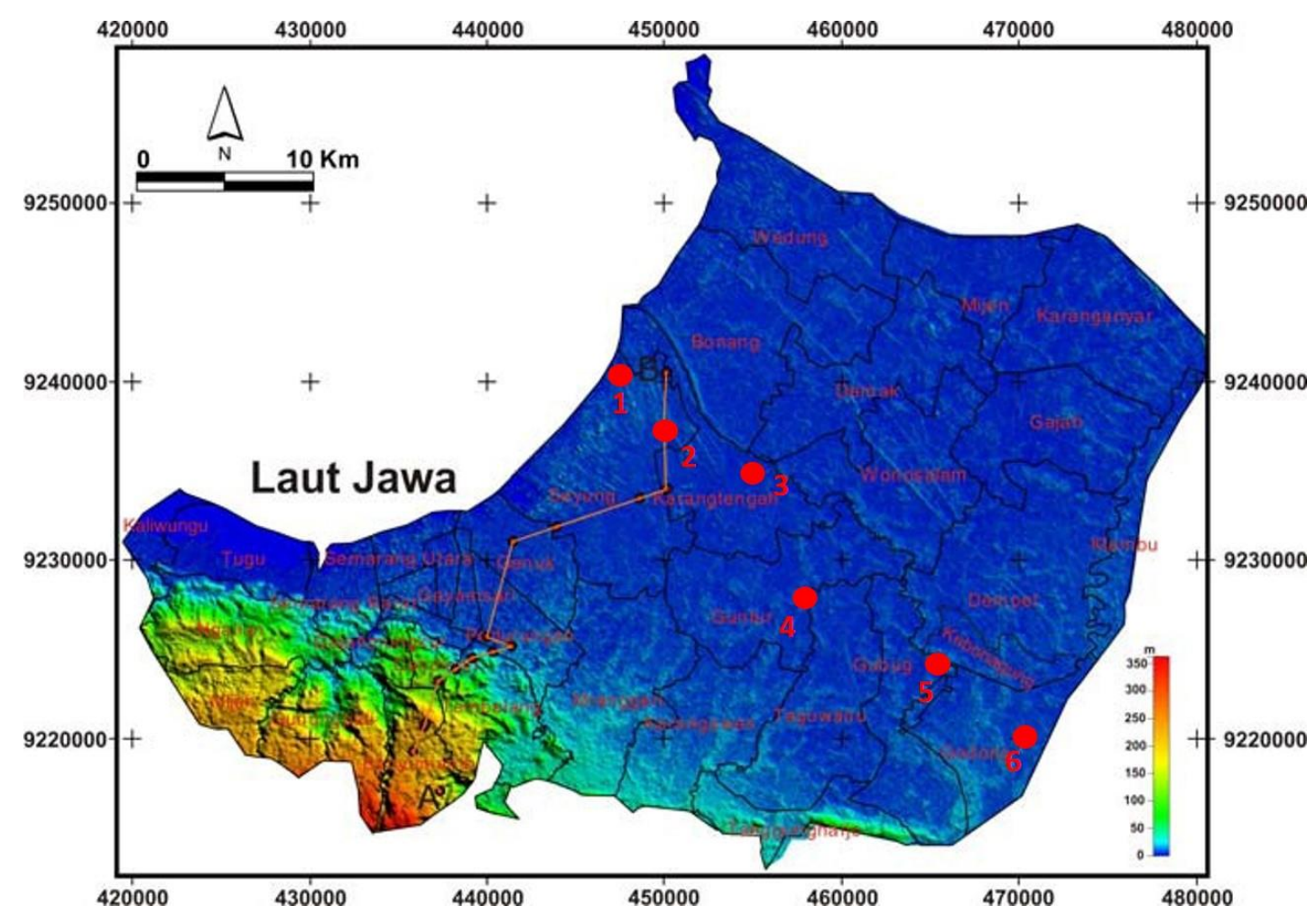

Gambar 1. Peta Lokasi Pengambilan Sampel Airtanah di Kabupaten Demak 


\section{Analisis Hidrogeokimia Airtanah}

Analisis karakteristik hidrokimia airtanah dilakukan dengan melakukan analisis tipe kimia airtanah dan analisis evolusi hidrogeokimia airtanah. Analisis tipe kimia airtanah didasarkan pada hasil pembuatan diagram stiff (Gambar 2), sedangkan analisis evolusi hidrogeokimia dilakukan dengan pembuatan diagram piper (Gambar 3). Hasil analisis dengan diagram stiff akan mampu membantu analisis proses intrusi air laut dan jenis batuan yang berperan sebagai akuifer (Hiscock, 2005), sedangkan analisis menggunakan diagram piper dapat digunakan untuk mengetahui evolusi hidrokimia airtanah yang terjadi di lokasi kajian (Hiscock, 2005; Younger, 2007).

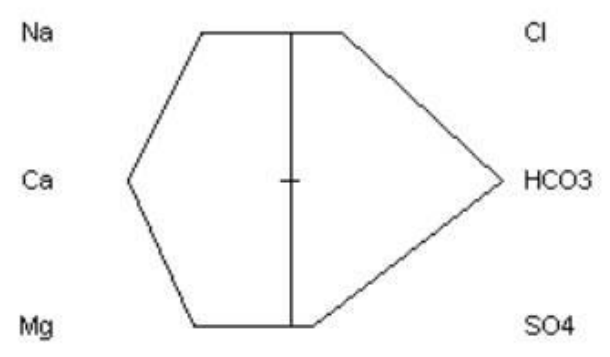

Gambar 2. Diagram Stiff

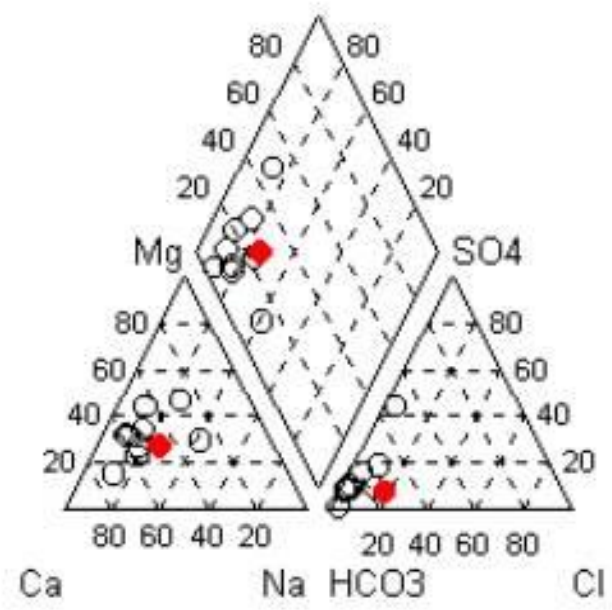

Gambar 3. Diagram Piper

\section{HASIL DAN PEMBAHASAN}

Wilayah Kepesisiran kabupaten Demak termasuk ke dalam Cekungan airtanah Semarang Demak (Gambar 4). Cekungan ini memiliki area yang cukup luas, yakni kurang lebih $1.386 \mathrm{~km}^{2}$ 
yang meliputi $321 \mathrm{~km}^{2}$ di wilayah Kota Semarang, 864 km² di wilayah Kabupaten Demak, 190 $\mathrm{km}^{2}$ di Kabupaten Grobogan serta $11 \mathrm{~km}^{2}$ di Kabupaten Kendal (Putranto, 2011). Morfologi Cekungan Semarang Demak secara umum dapat terbagi dalam dua bagian yakni dataran (plains) di bagian utara Semarang dan sebagian besar Demak yang digambarkan dengan warna biru pada Gambar 4, serta perbukitan dengan lereng rendah hingga tinggi di bagian selatan Kota Semarang yang digambarkan dengan warna kehijauan sampai kemerahan pada Gambar 4.

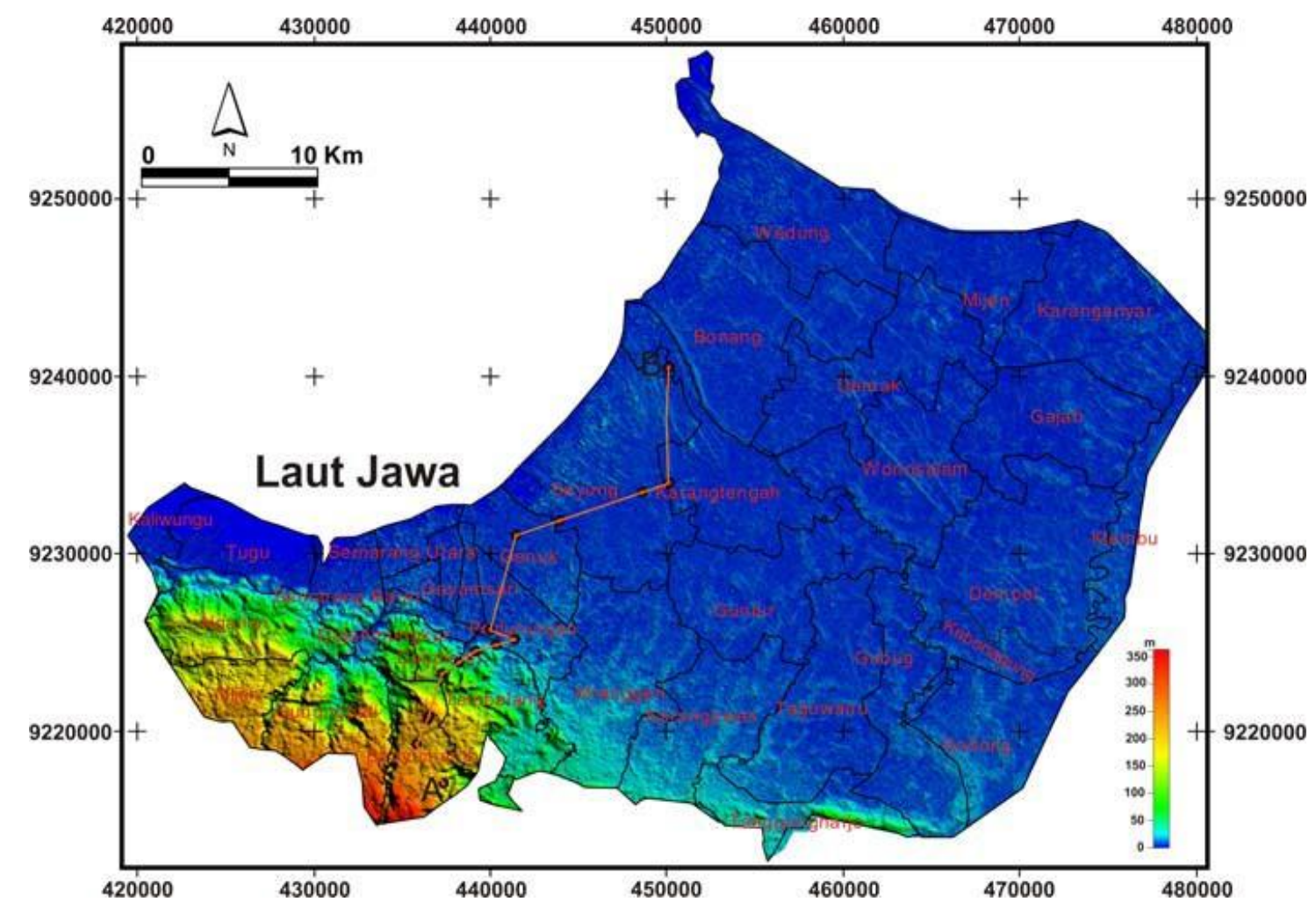

Gambar 4. Peta Digital Elevation Model (DEM) Cekungan Semarang Demak (Putranto, 2011)

Berdasarkan peta geologi regional lembar Magelang Semarang (Thanden dkk., 1996) serta lembar Kudus (Suwarti dan Wikarno, 1992), maka kondisi geologi di Cekungan Semarang Demak dari yang tertua sampai termuda tersusun oleh dua macam batuan yakni batuan sedimen yang berumur Tersier yakni Formasi Kerek dan Kalibeng, kemudian Formasi Damar dan Formasi Kaligetas yang berumur Kuarter serta endapan permukaan (aluvium) yang berumur Holosen. Formasi Kerek dan Kalibeng dominan tersusun oleh batulempung, napal dan setempat batugamping. Formasi tersebut terletak pada morfologi lereng rendah hingga menengah (lower to intermediate slope). Formasi Damar tersusun oleh konglomerat, batupasir tufaan dan 
breksi volkanik berupa lahar dan terletak pada morfologi dengan lereng sedang (intermediate slope), sedangkan Formasi Kaligetas tersusun oleh dominan produk volkanik seperti breksi volkanik, lava serta batupasir tufaan dan setempat batulempung. Formasi ini tersebar pada morfologi dengan lereng sedang hingga tinggi (intermediate to upper slope). Wilayah dataran (plains) didominasi oleh endapan aluvium pantai, sungai dan danau, yang terdiri dari lempung, lanau, pasir dan kerikil.

Secara umum, kondisi airtanah Cekungan Semarang Demak mengalir dari arah perbukitan di selatan menuju ke dataran di bagian utara. Hal itu berarti bahwa daerah pengisian (recharge area) terletak di Gunungapi Ungaran, sementara daerah pelepasan (discharge area) di dataran sepanjang pantai. Berdasarkan peta hidrogeologi regional lembar Semarang, airtanah mengalir dominan melalui ruang antar butir, sebagian melalui celah maupun rekahan dan di beberapa tempat dijumpai airtanah langka (Sunarto, 2008).

Berdasarkan data geologi dan hidrogelogi, maka disusun konseptual model sistem akuifer Cekungan Semarang Demak yang disajikan dalam sayatan melintang (cross section) A - B seperti terlihat Gambar 5. Sistem akuifer dibagi menjadi dua yakni akuifer bebas dan akuifer tertekan. Akuifer bebas tersebar dari intermediate slope hingga plains. Muka airtanah bebas (phreatic water level) semakin dalam ke arah selatan mengikuti ketinggian topografi. Airtanah di daerah dataran tersimpan pada endapan aluvium yang berupa lempung pasiran, pasir dan pasir tufaan serta batupasir, konglomerat dan breksi di daerah berlereng rendah hingga sedang. Akuifer tertekan terletak pada daerah lower slope hingga plains dengan muka airtanah tertekan (piezometric level) lebih rendah dibandingkan muka airtanah bebas. Akuifer tertekan merupakan multi layer akuifer yang dipisahkan oleh lapisan akuitar berupa lempung. Batuan dasar dari konsepual model ini tersusun oleh batulempung serta batugamping berumur Tersier, merupakan bagian dari Formasi Kerek serta Kalibeng bersifat kedap air (akuiklud). 


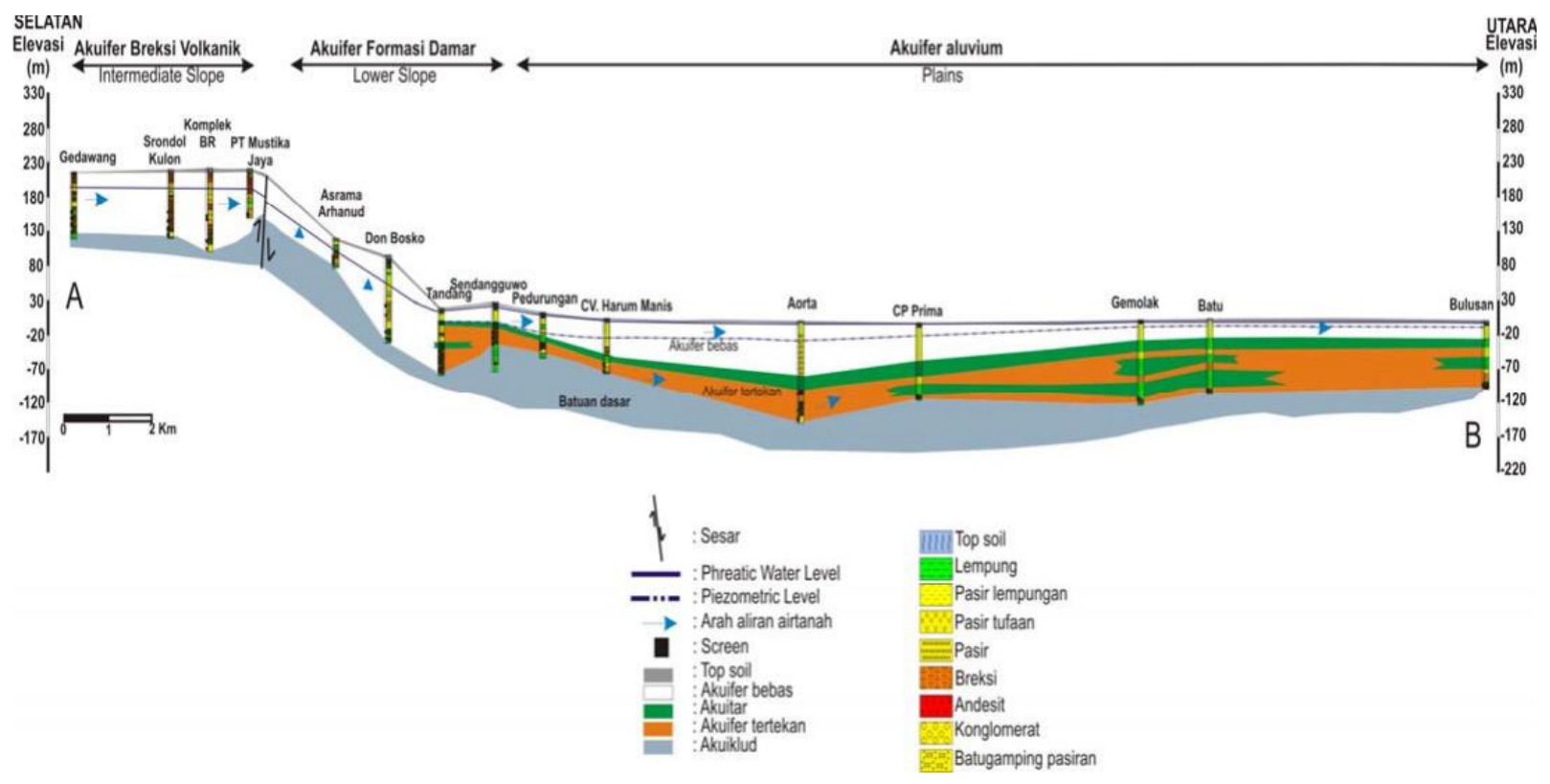

Gambar 5. Sketsa Akuifer di Cekungan Semarang Demak (Putranto, 2011)

Hasil analisis laboratorium terhadap sampel air artesis yang diambil di Dusun bedono menunjukkan bahwa tipe hidrogeokimia untuk empat sampel adalah $\mathrm{MgCl}_{2}$ yang menunjukkan pengaruh intrusi air laut (Aris et al., 2013) dan tipe $\mathrm{Na}(\mathrm{K}) \mathrm{HCO}_{3}$. Hal tersebut nampak dari Gambar 6 yang menyajikan diagram stiff dari masing-masing sampel airtanah. Kandungan natrium dimungkinkan berasal dari garam yang terjebak dalam material lempung yang membentuk lapisan kedap pada Formasi Kerek serta Kalibeng, sedangkan kandungan bikarbonat, kalsium dan magnesium dihasilkan oleh gamping dan dolomit yang menyusun formasi yang sama. Selain itu, kandungan tersebut berasal dari proses crosscontamination dari akuifer yang berada di atas akuifer tertekan. Kandungan magnesium, Kalsium dan bikarbonat yang tinggi merupakan cerminan pembentukan dari akuifer di pesisir Demak. Hal ini karena material yang membentuk Wilayah Kepesisiran demak berasal dari Perbukitan Rembang dan Perbukitan Kendeng yang memiliki material gamping, dolomit dan gamping dolomitan. Kandungan magnesium yang tinggi juga disebabkan adanya pengaruh air laut dari proses cebakan masa lampau seperti hasil penelitian Aris et al. (2013). 


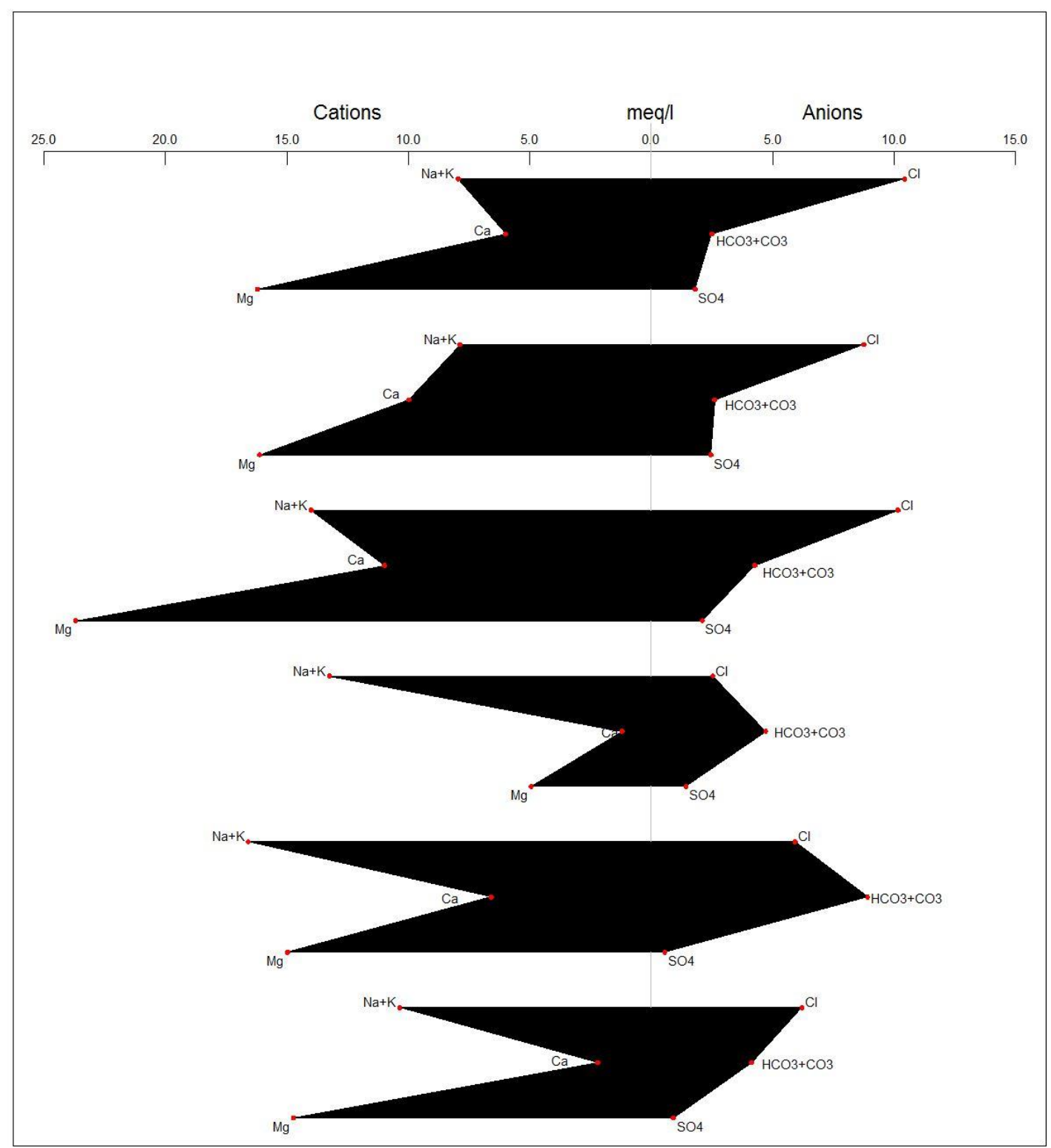

Gambar 6. Diagram Stiff dari Sampel Airtanah di Lokasi Kajian

Hasil analisis dengan menggunakan diagram piper menunjukkan bahwa empat sampel menunjukkan tipe kation magnesium, satu sampel tidak memiliki kation dominan dan satu sampel menunjukkan adanya tipe kation Natrium+Kalium (Gambar 7). Tipe anion dominan adalah ion klorida (empat sampel) dan ion bikarbonat (dua sampel). Tipe hidrogeokimia yang dominan berdasarkan diagram piper adalah $\mathrm{Mg}(\mathrm{Ca}) \mathrm{Cl}\left(\mathrm{SO}_{4}\right)$ sebanyak empat sampel, $\mathrm{CaMgHCO}_{3}$ satu sampel dan $\mathrm{Na}(\mathrm{K}) \mathrm{Cl}\left(\mathrm{SO}_{4}\right)$. Berdasarkan kajian tersebut, diketahui bahwa tipe 
hidrogeokimia dari airtanah di lokasi kajian mengalami evolusi dari tipe $\mathrm{CaHCO}_{3}$ menjadi $\mathrm{MgCl}_{2}$ sebagai air payau dan menjadi $\mathrm{Na}(\mathrm{K}) \mathrm{Cl}$ sebagai air asin.

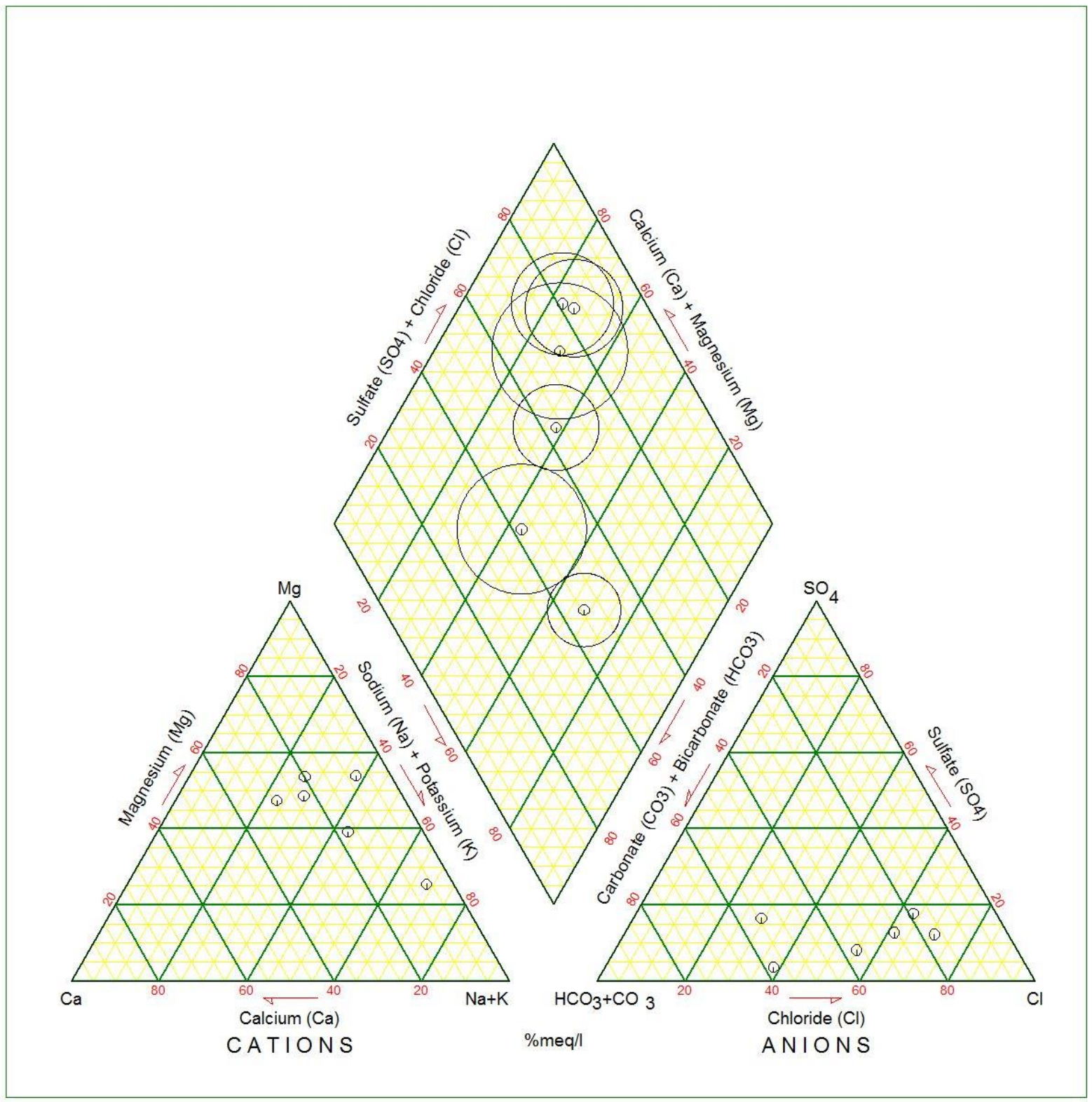

Gambar 7. Diaagram Piper dari Airtanah di Lokasi Kajian

\section{KESIMPULAN}

Berdasarkan hasil analisis laboratorium terhadap sampel airtanah yang diambil di lokasi kajian, diketahui bahwa tipe hidrogeokimia untuk empat sampel adalah $\mathrm{MgCl}_{2}$ yang menunjukkan pengaruh intrusi air laut dan tipe $\mathrm{Na}(\mathrm{K}) \mathrm{HCO}_{3}$ yang menunjukkan pengaruh intrusi air laut dan pengaruh batuan karbonat yang masih kuat. Tipe hidrogeokimia yang dominan 
berdasarkan diagram piper adalah $\mathrm{Mg}(\mathrm{Ca}) \mathrm{Cl}\left(\mathrm{SO}_{4}\right)$, yakni sebanyak empat sampel. Tipe hidrogeokimia yang lain meliputi $\mathrm{CaMgHCO}_{3}$ yakni sebanyak satu sampel dan $\mathrm{Na}(\mathrm{K}) \mathrm{Cl}\left(\mathrm{SO}_{4}\right)$ sebanyak satu sampel. Berdasarkan kajian tersebut, diketahui bahwa tipe hidrogeokimia dari airtanah di lokasi kajian mengalami evolusi dari tipe $\mathrm{CaHCO}_{3}$ menjadi $\mathrm{MgCl}_{2}$ sebagai air payau dan menjadi $\mathrm{Na}(\mathrm{K}) \mathrm{Cl}$ sebagai air asin.

\section{PENGAKUAN}

Makalah ini merupakan bagian dari hibah penelitian Dosen Fakultas geografi UGM Tahun 2015 dengan judul "Analisis Dampak Banjir Pesisir (Rob) Terhadap Sumberdaya Air di Wilayah Kepesisiran Kabupaten Demak Provinsi Jawa Tengah". Penelitian ini didanai oleh Biaya Bantuan Operasional Perguruan Tinggi Negeri (BOPTN). Terima kasih kami sampaikan kepada semua pihak yang telah berkontribusi dan membantu terlaksananya penelitian ini.

\section{DAFTAR PUSTAKA}

Aris, A.Z.; Praveena, S.M. dan Isa, N.M. 2013. Groundwater Composition and Geochemical Controls in Small Tropical Island of Malaysia: A Comparative Study. dalam Wetzelhuetter, C. 2013. Groundwater in the Coastal Zones of Asia-Pacific. New York: Springer.

Bryan, E. 2005. Natural Hazards, Second Edition. Cambridge: Cambridge University Press.

Dragoni, W. dan Sukhija, B.S. 2008. Climate Change and Groundwater: A Short Review. dalam Dragoni, W. dan Sukhija, B.S. 2008. Climate Change and Groundwater. London: Geological Society.

Ducci, D. dan Tranfaglia, G. 2008. Effects of Climate Change on Groundwater Resources in Campania (Southern Italy). dalam Dragoni, W. dan Sukhija, B.S. 2008. Climate Change and Groundwater. London: Geological Society.

Fetter, C.W. 1988. Applied Hydrogeology, Second Edition. New York: Macmillan Publishing Company.

Gilli, E.; Mangan, C. dan Mudry, J. 2012. Hydrogeology: Objective, Methods, Applications. Boca Raton: CRC Press.

Hiscock, K.M. 2005. Hydrogeology: Principles and Practice. Oxford, United Kingdom: Blackwell Publishing.

IPCC. 2007. The Physical Science Basis - Summary for Policymakers. Contribution of WGI to The Fourth Assessment Report of The Intergovernmental Panel on Climate Change. Diakses dari http://www.ipcc.ch/ipccreport/ar4-wgl.htm.

Lagudu, S.; Rao, V.V.S.G.; Prasad, P.R. dan Sarma, V.S. 2013. Use of Geophysical and Hydrochemical Tolls to Investigate Seawater Intrusion in Coastal Alluvial Aquifer Andhra 
Pradesh, India. dalam Wetzelhuetter, C. 2013. Groundwater in the Coastal Zones of AsiaPacific. New York: Springer.

Marfai, M.A. dan King, L. 2008a. Tidal Inundation Mapping Under Enhanced Land Subsidence in Semarang, Central Java Indonesia. Natural Hazards, 44: 93-109.

Marfai, M.A. dan King, L. 2008b. Potential Vulnerability Implications of Coastal Inundation Due To Sea Level Rise for The Coastal Zone of Semarang City, Indonesia. Environmental Geology, 54:1235-1245.

Meyboom, P. 1967. Mass-Transfer Studies to Determine the Groundwater Regime of Permanent Lakes in Hummocky Moraine of Western Canada. Journal of Hydrology, 5: 117-142.

Polemio, M dan Casarano, D. 2008. Climate Change, Drought and Groundwater Availability in Southern Italy. dalam Dragoni, W. dan Sukhija, B.S. 2008. Climate Change and Groundwater. London: Geological Society.

Putranto, T.T. 2011. Aplikasi Pemodelan Aliran Airtanah Dalam Konsep Pengelolaan Airtanah Berbasis Cekungan. Proceeding Olimpiade Karya Tulis Inovatif (OKTI) 2011.

Sherif, M.; Almulla, M. dan Shetty, A. 2013. Seawater Intrusion Under Current Sea-Level Rise: Processes Accompanying Coastline Transgression. dalamWetzelhuetter, C. 2013. Groundwater in the Coastal Zones of Asia-Pacific. New York: Springer.

Sunarto. 2004. Perubahan Fenomena Geomorfik Daerah Kepesisiran di Sekeliling Gunungapi Muria Jawa Tengah (Kajian Geomorfologi). Disertasi. Universitas Gadjah Mada.

Suwarti, T. dan Wikarno, S. 1992. Peta Geologi Lembar Kudus, Jawa. Pusat Penelitian dan Pengembangan Geologi, Bandung.

Wetzelhuetter, C. 2013. Groundwater in the Coastal Zones of Asia-Pacific. New York: Springer.

Winter, T.C. 1999. Relation of Stream, Lakes and Wetlands to Groundwater Flow System. Hydrogeology Journal, 7: 28-45.

Younger, P.L. 2007. Groundwater in The Environment: An Introduction. Oxford, United Kingdom: Blackwell Publishing. 